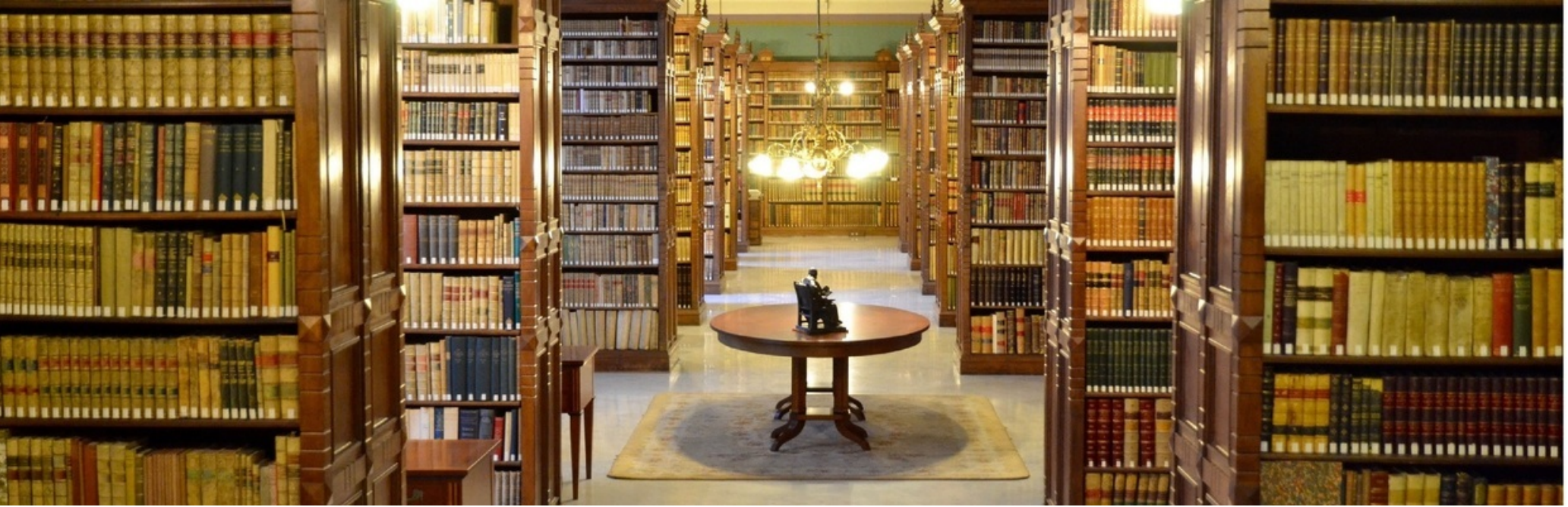

\title{
Editorial Volume 8, Issue 4
}

$\begin{aligned} \text { Authors: } & \text { Stephan Seiler } \\ \text { Submitted: } & \text { 2. November } 2021 \\ \text { Published: } & \text { 2. November } 2021 \\ \text { Volume: } & 8 \\ \text { Issue: } & 5 \\ \text { Affiliation: } & \text { Josha Journal. Freiburg, Germany } \\ \text { Languages: } & \text { English } \\ \text { Keywords: } & \text { Editorial, JOSHA Journal, } 2021 \text { Volume 8, Issue } 4 \\ \text { Categories: } & \text { News and Views } \\ \text { DOI: } & \text { 10.17160/josha.8.5.787 }\end{aligned}$

\section{Abstract:}

This issue is a great example for the strength at Josha. Diversity! We hope you enjoy reading our articles from all around the world. Issue 4 features articles in Spanish, Italian, German, English, from countries like Nigeria, Australia, Germany, Italy, Kosovo, Colombia, USA, Argentina in the fields of Medicine, Humanities, Music and Arts, Modeling and Simulation. In addition to the various articles we also nominated our Demetrios Award 2021 winners. Read our editorial for more information about the authors and their great work! What a joy to feel connected with the world through reading. We are looking forward to publishing with YOU! 


\section{Editorial}

Volume 8, Issue 4

Dear readers,

after an exciting selection period, we are happy to introduce you to our Demetrios Award winners this year. All selected entries can be found in our current issue of the Josha Journal. Also, all other submitted works. Many thanks to all applicants and the team around Roland Mertelsmann for the contributions and the selection of the award winners.

The prize money comes from the International Academy of Sciences, Humanities and Arts (IASHA e.V) and is complemented by the Roland Mertelsmann BioThera Foundation. This year's winners are:

\section{Doctoral thesis:}

Gustavo Iván Rosero Yánez for his work entitled: "Desarrollo de microdispositivos para Análisis de Células y Biomoléculas - Microdevice Development for Analysis of Cells and Biomolecules".

\section{Master's thesis:}

Avani Sapre for his work entitled: "Three - Dimensional Culture For Continuous Long Term Live Cell Imaging".

\section{Bachelor thesis:}

Jochen Wahl for his work entitled "Grundfrequenz und harmonische Oberschwingung: die Obertonreihe musikalische Physik im fächerübergreifenden Unterricht - The Overtone Series - Musical Physics in Interdisciplinary Teaching".

We would like to take this opportunity to congratulate the award winners once again and wish them all the best for their future young professional careers!

Another Corona year is drawing to a close. We wish all readers of the Josha Journal good health and we are looking forward to more exciting articles in 2022.

Now we hope you enjoy reading the journal.

Dr. Stephan Seiler

Vice President

International Academy of Sciences, Humanities and Arts 


\section{Volume 8, Issue 4}

\section{Gustavo Iván Rosero Yánez}

Desarrollo de microdispositivos para Análisis de Células y Biomoléculas - Microdevice Development for Analysis of Cells and Biomolecules

\section{Angela Gissette Caro Delgado and Yury Estefania Perdomo Jurado}

Adherencia al Tratamiento y Razones para vivir en Pacientes con ECNT durante el COVID-19 - Treatment adherence and Reasons for Living in Patients with CNCD during COVID-19

\section{Valentino Beorda}

Fotógrafo de estrellas - Star Photographer

\section{Camila Eymy Alejandra Hernandez}

Representaciones Sociales sobre Violencias en la Familia de Estudiantes Universitarios - Social representations on Violence in Families of University Students

\section{Jochen Wahl}

Grundfrequenz und harmonische Oberschwingung: die Obertonreihe - musikalische Physik im fächerübergreifenden Unterricht - The Overtone Series - musical Physics in interdisciplinary Teaching

\section{Giovanni Corvino}

RECENSIONE: La Macchina del Tempo - Quando l'Europa ha iniziato a scrivere la storia del mondo Review: The Time Machine - When Europe Began to Write World History

\section{Monica Hickson}

Life after the Pandemic

\section{Carlos Andrés Prada Rogéliz}

A proposed methodological framework for the Spatial and temporal Calibration of a Large River Basin Hydrological Model

\section{Zana Sllamniku Dalipi and Fehim Haliti}

The Importance of non-surgical Periodontal Therapy in Patients with Drug gingival Enlargement - Case $\underline{\text { Series }}$

\section{Johanna Patton}

The Together Project: Holi in Jodhpur, India

\section{Robert Kaplan}

The Last Leap of Vere Gordon Childe: His Final Days

\section{Usman Al-amin}

Clitoridectomy among Shuwa Arabs of Borno, Nigeria

\section{JosHA joshajournal}

